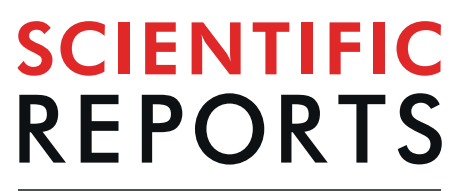

natureresearch

\title{
Food availability modulates the combined effects of ocean acidification and warming on fish growth
}

\author{
Louise Cominassi ${ }^{1 *}$, Marta Moyano $\mathbb{1}^{1}$, Guy Claireaux ${ }^{2}$, Sarah Howald ${ }^{1,3}$, Felix C. Mark $\mathbb{D}^{3}$, \\ José-Luis Zambonino-Infante ${ }^{4}$ \& Mron A. Peck ${ }^{1}$
}

When organisms are unable to feed ad libitum they may be more susceptible to negative effects of environmental stressors such as ocean acidification and warming (OAW). We reared sea bass (Dicentrarchus labrax) at 15 or $20^{\circ} \mathrm{C}$ and at ambient or high $P \mathrm{CO}_{2}\left(650\right.$ versus $1750 \mu \mathrm{atm} P \mathrm{CO}_{2} ; \mathrm{pH}=8.1$ or 7.6) at ad libitum feeding and observed no discernible effect of $\mathrm{PCO}_{2}$ on the size-at-age of juveniles after $277\left(20^{\circ} \mathrm{C}\right)$ and $367\left(15^{\circ} \mathrm{C}\right)$ days. Feeding trials were then conducted including a restricted ration ( $25 \%$ ad libitum). At $15^{\circ} \mathrm{C}$, growth rate increased with ration but was unaffected by $\mathrm{PCO}_{2}$. At $20^{\circ} \mathrm{C}$, acidification and warming acted antagonistically and low feeding level enhanced $P \mathrm{CO}_{2}$ effects. Differences in growth were not merely a consequence of lower food intake but also linked to changes in digestive efficiency. The specific activity of digestive enzymes (amylase, trypsin, phosphatase alkaline and aminopeptidase $\mathrm{N}$ ) at $20^{\circ} \mathrm{C}$ was lower at the higher $\mathrm{PCO}_{2}$ level. Our study highlights the importance of incorporating restricted feeding into experimental designs examining OAW and suggests that $a d$ libitum feeding used in the majority of the studies to date may not have been suitable to detect impacts of ecological significance.

An amalgam of abiotic and biotic factors interact in nature to impact the vital rates of marine organisms ${ }^{1-3}$ and understanding the cumulative effect of multiple stressors on marine organisms is currently one of the top priorities for ecologists ${ }^{4}$. Unfortunately, the effect of multiple stressors is challenging to predict because their interaction can be either additive (the combined response is the sum of responses to individual factors), synergistic (the combined response is greater than the sum of responses to the independent factors) or antagonistic (the combined response is smaller than the response to either single $)^{5}$. For example, the projected increase of the concentration of carbon dioxide $\left(\mathrm{CO}_{2}\right)$ in the atmosphere by 2100 (from $280-410 \mathrm{ppm}$ to $730-1020 \mathrm{ppm}^{6,7}$ ) is expected to cause both ocean acidification $\left(\mathrm{OA}\right.$, decrease in $\mathrm{pH}$ by 0.3 to 0.5 units $\left.^{6}\right)$ and continued global warming $\left(0.2^{\circ} \mathrm{C}\right.$ increase per decade in the past 30 years $\left.^{8}\right)$. Research efforts are underway to understand how OAW will combine to impact on the vital rates of marine biota ${ }^{9,10}$.

When consumers in marine food webs have been exposed to OAW, a range of changes affecting growth responses have been reported ${ }^{11}$. The level of OAW projected for 2100 caused significant reductions in the growth of mollusks and echinoderms, but a variety of responses has been reported in fish. For example, larval sea bass (Dicentrarchus labrax) incubated in four treatment groups $\left(17\right.$ and $19^{\circ} \mathrm{C}, 600$ and $1000 \mu$ atm $\left.P C \mathrm{O}_{2}\right)$ grew significantly faster in the warmer and higher $\mathrm{PCO}_{2}$ treatment ${ }^{12}$ whereas growth of Senegalese sole (Solea senegalensis) larvae increased with temperature but decreased with increasing $P \mathrm{CO}_{2}{ }^{13}$. A main conclusion to be drawn from the mixed results reported for fish is that the effect of OA and OAW can be life stage- and species-specific, and warming could either offset or aggravate any impacts of $\mathrm{OA}^{14}$. An important caveat is that the vast majority of studies investigating the effects of OA or OAW, on fish or other marine animals, has been performed on

\footnotetext{
${ }^{1}$ Institute of Marine Ecosystem and Fisheries Science, Center for Earth System Research and Sustainability (CEN), University of Hamburg, 22767, Hamburg, Germany. ${ }^{2}$ Université de Bretagne Occidentale, LEMAR (UMR 6539), Centre Ifremer de Bretagne, 29280, Plouzané, France. ${ }^{3}$ Alfred Wegener Institute Helmholtz Centre for Polar and Marine Research, Integrative Ecophysiology, 27570, Bremerhaven, Germany. ${ }^{4}$ Ifremer, LEMAR (UMR 6539), Laboratory of Adaptation, Reproduction and Nutrition of Fish, Centre Ifremer de Bretagne, 29280, Plouzané, France.

*email: louise.cominassi@gmail.com
} 


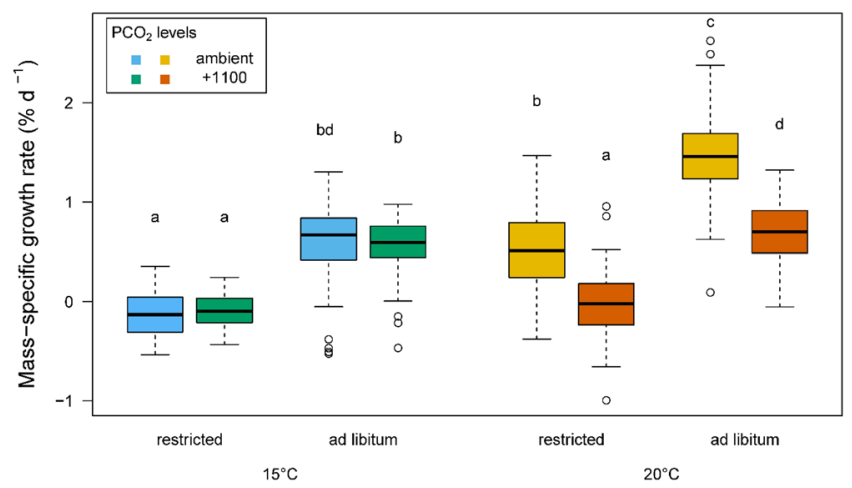

Figure 1. Box and whisker plots of mass-specific growth rate (SGR) of individually tagged juveniles sea bass $\left(\mathrm{n}=103\right.$ to 115 per box) reared at two temperatures $\left(15\right.$ and $\left.20^{\circ} \mathrm{C}\right)$, two $P_{C O}$ levels and two feeding levels ${ }^{94}$. Different letters denote significant differences (Student-Newman-Keuls test, $\mathrm{p}<0.05$ ) between each condition. The whiskers denote the $10^{\text {th }}$ and $90^{\text {th }}$ percentiles, the box denotes the $25^{\text {th }}$ and $75^{\text {th }}$ percentiles, the median value is shown (horizontal line) as well as outliers (points).

individuals fed ad libitum. Ad libitum rations may provide ample energy allowing organisms to compensate for potential negative impacts of sub-optimal levels of temperature and/or $\mathrm{PCO}_{2}$ on energy acquisition, dissipation and allocation. For instance, invertebrates such as corals, mussels and oysters maintained on restricted rations displayed more deleterious effects to OAW than well-fed conspecifics ${ }^{15-18}$. In fish, only very recent studies have examined the influence of the interaction between $\mathrm{CO}_{2}$ and food ration on larval growth and development ${ }^{19-22}$. They showed either no supplementary effect with food restriction ${ }^{19,20}$ or observed larger individuals but with important organ damages 22 .

Covering obligatory maintenance costs (standard metabolic rate) is generally the first priority when organisms allocate available energy. When additional food resources are available, however, the corresponding energy allocation to discretionary activities is based on fine-tuned trade-offs that depend on the organisms' activities, physiological state and environment. For instance, during long-term food restriction, energy is not available to fuel the production of digestive enzymes which inevitably impairs digestive capacity and reduces rates of growth and protein synthesis in fish ${ }^{23}$. Environmental changes might also impact energy allocated for digestion and consequently for growth. For example, 15 months after European sea bass larvae were exposed to an 8-day hypoxic episode, their growth rates and protein digestive capacity (lower trypsin activity in the pancreas and aminopeptidase $\mathrm{N}$ and alkaline activity in the intestine) were still lower than those from siblings maintained in normoxia ${ }^{24}$. Information on how OA will impact the digestive function of marine organisms is relatively scarce ${ }^{25}$. The hypothesis is that $\mathrm{OA}$ will act as a metabolic stressor, similar to hypoxia, causing reduced digestive capacity. If OA impaired acid base regulation, more energy might be allocated to buttress this homeostasis (or others defense mechanisms) at the cost of digestive efficiency. Although there is no evidence yet that digestive function might be affected, Strobel et al. ${ }^{26}$ demonstrated that in an exposure of an Antarctic fish to $2000 \mu$ atm $P \mathrm{CO}_{2}$, regulation of acid-base balance occurred at the detriment of other processes such as calcification or osmoregulation likely due to changes in energy allocation.

We examined the growth rate and digestive capacity of juvenile sea bass (Dicentrarchus labrax) fed ad libitum or restricted (25\% of ad libitum) rations at an ambient and an elevated ( $+1100 \mu$ atm) level of $P \mathrm{O}_{2}$. Two trials were conducted using juveniles that had been reared for nearly a year under OA conditions since the early larval stage. The first trial was performed on fish reared at $20^{\circ} \mathrm{C}$ while the second trial was conducted about 2 months later on fish reared at $15^{\circ} \mathrm{C}$. The time between trials allowed the $15^{\circ} \mathrm{C}$ fish to grow to a body size more comparable to that of the warm-acclimated fish at the start of the first trial. We focused on understanding the underlying mechanisms of potential impacts of OA on growth including feed conversion efficiency (FCE), stomach $\mathrm{pH}$ and the activity of key digestive enzymes. Although OA had no discernable impact on size-at-age of sea bass feeding at ad libitum, expectations were that elevated $\mathrm{PCO}_{2}$ combined with restricted feeding would cause decrements in growth performance in these fish, particularly at the warmer temperature. Incorporating feeding level treatments in a long-term exposure to OAW, this study reveals that the elevated temperature and elevated $\mathrm{PCO}_{2}$ levels acted antagonistically on juvenile fish growth and highlights the need to re-examine the design of experiments attempting to test "real world" effects of climate-driven changes in abiotic factors.

\section{Results}

Growth performance. Prior to the trial, for each temperature treatment, no significant differences were observed in the mass-at-age of fish reared since larvae at different $\mathrm{PCO}_{2}$ levels (measurements conducted at 277 dph and $367 \mathrm{dph}$ for $20^{\circ} \mathrm{C}$ and $15^{\circ} \mathrm{C}$, respectively; see Fig. S2). No mortalities occurred during the trials and individual SGR (specific growth rate) ranged from -0.53 to $1.30 \% \mathrm{~d}^{-1}$ at $15^{\circ} \mathrm{C}$ and from -0.99 to $2.62 \% \mathrm{~d}^{-1}$ at $20^{\circ} \mathrm{C}$ (Fig. 1). Growth appeared to be similar across all body sizes, from relatively small to large fish at $15^{\circ} \mathrm{C}(\mathrm{S} 3)$ and $20^{\circ} \mathrm{C}$ (S4). At $15^{\circ} \mathrm{C}$, SGR was not affected by $\mathrm{PCO}_{2}$ and, not unexpectedly, fish fed ad libitum grew significantly faster than those fed restricted rations (ANOVA, $\mathrm{p}<0.001$ ). A different pattern emerged at $20^{\circ} \mathrm{C}$, where SGR was significantly affected not only by ration level but also by $\mathrm{PCO}_{2}$, as indicated by a significant interaction (ANOVA, $\mathrm{p}<0.001$ ). For fish fed ad libitum, the SGR of ambient fish was $110 \%$ higher than fish from the elevated 


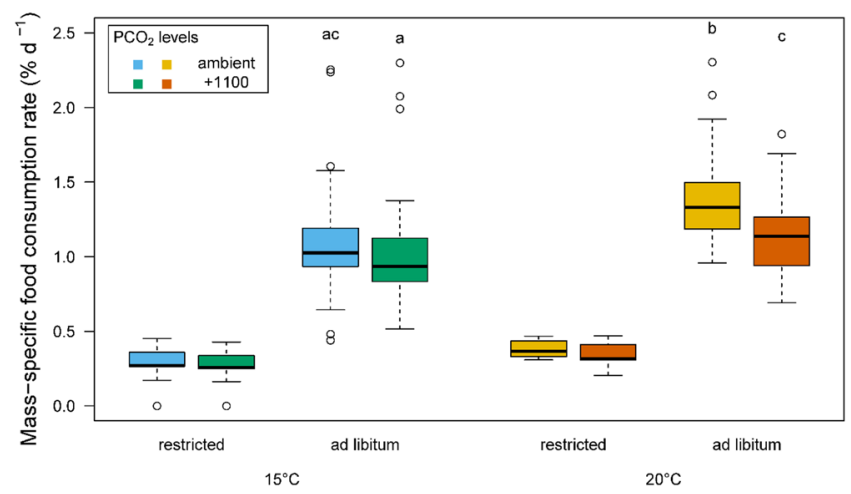

Figure 2. Box and whisker plots of the mass-specific food consumption rate at two temperatures $\left(15\right.$ and $20^{\circ} \mathrm{C}$, two $\mathrm{PCO}_{2}$ levels and two feeding levels $(\mathrm{n}=103 \text { to } 115 \text { per box })^{94}$. Differences in specific food consumption rate were tested between ad libitum groups. Different letters denote significant differences (nested ANOVA, $\mathrm{p}<0.05$ ). The whiskers denote the $10^{\text {th }}$ and $90^{\text {th }}$ percentiles, the box denotes the $25^{\text {th }}$ and $75^{\text {th }}$ percentiles, the median value is shown (horizontal line) as well as outliers (points).

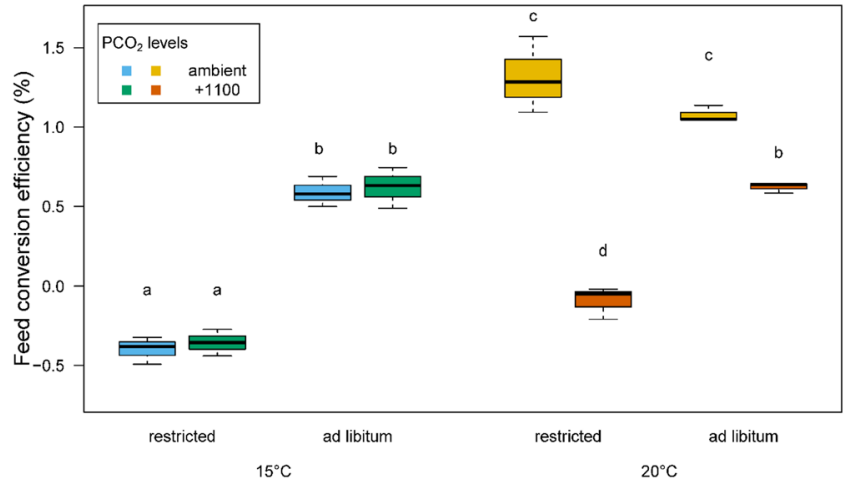

Figure 3. Box and whisker plots of feed conversion efficiency (FCE) of juvenile sea bass reared at two temperatures, two $\mathrm{PCO}_{2}$ levels and at two feeding levels $(\mathrm{n}=3 \text { mean, tank values per box })^{94}$. Different letters denote significant differences (Student-Newman-Keuls test, $\mathrm{p}<0.05$ ) between each treatment group. The whiskers denote the $10^{\text {th }}$ and $90^{\text {th }}$ percentiles, the box denotes the $25^{\text {th }}$ and $75^{\text {th }}$ percentiles and the median value is shown (horizontal line).

$(+1100 \mu \mathrm{atm})$ treatment. In restricted feeding condition, the difference was even more pronounced, as the +1100 -acclimated fish lost mass, while the groups of fish reared at ambient $P C \mathrm{O}_{2}$ had a mean SGR of $0.5 \% \mathrm{~d}^{-1}$.

For ad libitum fed fish, the temperature (ANOVA, $\mathrm{p}<0.001$ ), the $P \mathrm{CO}_{2}$ level (ANOVA, $\mathrm{p}<0.001$ ) and the interaction between the two (ANOVA, $\mathrm{p}=0.004$ ) significantly affected the specific food consumption rate. At $15^{\circ} \mathrm{C}$, the specific food consumption rate was similar between the two $\mathrm{PCO}_{2}$ levels (Student-Newman-Keuls multiple comparison test, $\mathrm{p}=0.051$ ), while at $20^{\circ} \mathrm{C}$ the specific food consumption rate was higher in the ambient $\left(1.38(0.04) \% \mathrm{~d}^{-1}\right)$ compared to the $+1100 \mathrm{PCO}_{2}\left(1.12(0.03) \% \mathrm{~d}^{-1}\right)$ treatment group (Fig. 2). Importantly, the specific food consumption rate was similar between fish at $15^{\circ} \mathrm{C}$ in the ambient treatment and those at $20^{\circ} \mathrm{C}$ in the $+1100 \mathrm{PCO}_{2}$ treatment (Student-Newman-Keuls multiple comparison test, $\mathrm{p}=0.285$ ). The day-to-day feeding patterns of fish in the ad libitum treatments were variable and lacked any regular periodicity (Fig. S5). The total daily food intake at $20^{\circ} \mathrm{C}$, however, was lower in the ambient compared to the $+1100 \mathrm{PCO}_{2}$ treatment on 13 of the 18 days (nested ANOVA, $\mathrm{p}<0.001$, Fig. S5).

The FCE (feed conversion efficiency) was highest for fish in the ambient $P^{\circ} \mathrm{O}_{2}$ treatment at $20^{\circ} \mathrm{C}(>1.0)$ and was reduced by almost half $(<0.6)$ in fish at $20^{\circ} \mathrm{C}$ in the +1100 treatment. At $20^{\circ} \mathrm{C}$ and ambient $P \mathrm{CO}_{2}$, the FCE of fish fed restricted and ad libitum rations was not significantly different. In contrast, FCE in fish in the +1100 and restricted ration treatment was negative at both temperatures (mean $( \pm S E) ;-0.35(0.08)$ and $-0.09(0.10)$ for 15 and $20^{\circ} \mathrm{C}$, respectively). The level of $P_{C O}$ had a significant effect on FCE at $20^{\circ} \mathrm{C}$ (ANOVA, $\mathrm{p}<0.001$ ) but not at $15^{\circ} \mathrm{C}$. The largest difference in FCE between the ambient and $+1100 \mathrm{PCO}_{2}$ treatments was observed at both feeding levels at $20^{\circ} \mathrm{C}$ (Fig. 3).

Kinetics of stomach $\mathrm{pH}$. Prior to feeding, mean $( \pm \mathrm{SE})$ stomach $\mathrm{pH}$ ranged from $6.17(0.40)$ to $7.15(0.07)$ and was similar at both temperatures, $P \mathrm{CO}_{2}$ levels and feeding levels. In all treatments, acid was rapidly secreted after feeding and $\mathrm{pH}$ declined. The lowest $\mathrm{pH}$ values were measured at the first, two post-prandial sampling times (between 3 and $9 \mathrm{hrs}$ post-feeding). Stomach pH after $3\left(15^{\circ} \mathrm{C}\right)$ and $4\left(20^{\circ} \mathrm{C}\right)$ hrs post feeding was similar among treatments (Kruskal-Wallis, $\mathrm{p}=0.719$ and $\mathrm{p}=0.117$ for 15 and $20^{\circ} \mathrm{C}$, respectively), as well as after $8\left(15^{\circ} \mathrm{C}\right)$ and 9 

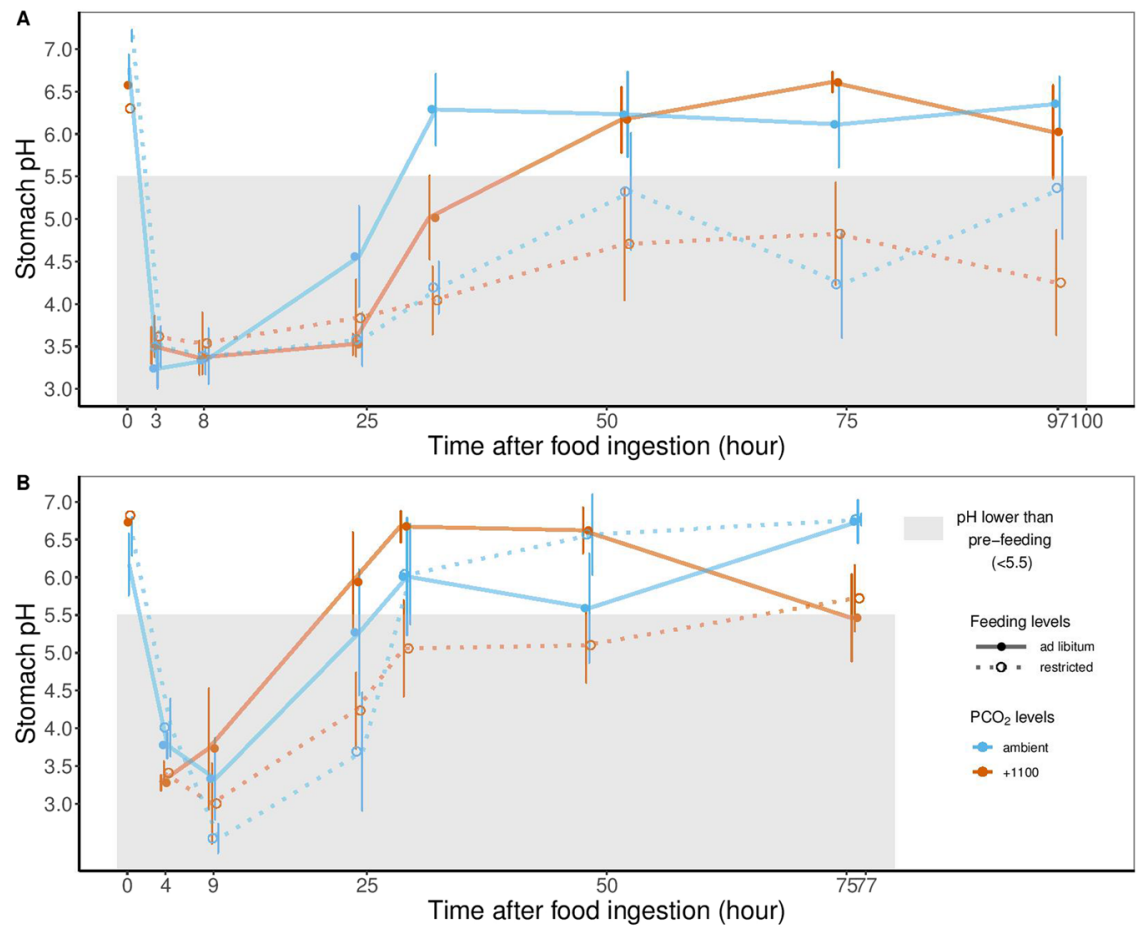

Figure 4. Post-prandial kinetics of stomach $\mathrm{pH}$ in juvenile sea bass ${ }^{94}$. Symbols display the mean $( \pm \mathrm{SE}, \mathrm{n}=8)$ for fish reared at two $\mathrm{PCO}_{2}$ levels (colors) and two feeding levels (shape) at either (A) $15^{\circ} \mathrm{C}$ or $(\mathbf{B}) 20^{\circ} \mathrm{C}$. In both panels, the lines are model predictions (LME).

$\left(20^{\circ} \mathrm{C}\right.$ ) hrs post-feeding (Kruskal-Wallis, $\mathrm{p}=0.996$ and $\mathrm{p}=0.725$ for 15 and $20^{\circ} \mathrm{C}$, respectively). After this initial decrease, the time course of stomach $\mathrm{pH}$ depended on the rearing treatment. At $15^{\circ} \mathrm{C}$, the time needed for stomach $\mathrm{pH}$ to return above a standard value (5.5) was significantly affected by feeding level (ANOVA, $\mathrm{p}<0.001$ ). The return was slower for fish fed restricted feeding levels (Fig. 4). At $20^{\circ} \mathrm{C}$, the kinetics of stomach pH of fish from the restricted feeding $+1100 \mu \mathrm{atm}$ treatment were significantly different (Tukey, $\mathrm{p}=0.034$ ) compared to the $a d$ libitum one. Fish fed restricted rations at $+1100 \mu$ atm took nearly twice as long to return to pre-feeding $\mathrm{pH}$ values (e.g. 48 versus $26 \mathrm{hrs}$ ).

Enzyme measurement. The total activity of each of the four tested enzymes was significantly lower at the colder compared to the warmer temperature (ANOVA, $\mathrm{p}<0.001$ ). Total enzyme activity also tended to be higher in fish fed ad libitum versus restricted rations (Fig. 5). At $15^{\circ} \mathrm{C}$, the total activity of AP (alkaline phosphatase) was significantly higher for fish on the ad libitum versus the restricted ration (ANOVA, $\mathrm{p}<0.001$; Fig. $5 \mathrm{G}$ ). At $20^{\circ} \mathrm{C}$, the total activity of trypsin was significantly higher for fish on the ad libitum versus restricted rations (ANOVA, $\mathrm{p}=0.005$ ) (Fig. 5D).

Significant reductions in the specific activities of AP (ANOVA, $\mathrm{p}<0.001$ ) and aminopeptidase N (ANOVA, $\mathrm{p}=0.007)$ were observed in fish at $15^{\circ} \mathrm{C}$ compared to $20^{\circ} \mathrm{C}$. At $15^{\circ} \mathrm{C}$, AP was significantly lower in fish fed restricted versus ad libitum rations (ANOVA, $\mathrm{p}<0.001$; Fig. $5 \mathrm{E}$ ). In contrast, at $20^{\circ} \mathrm{C}$ the specific activity of AP was higher in fish fed restricted rations (Fig. $5 \mathrm{~F}$ ). At $15^{\circ} \mathrm{C}$, despite a tendency for the specific activity of all four enzymes to be higher at the high versus the ambient $\mathrm{PCO}_{2}$ level, no significant differences were found (ANOVA, $\mathrm{p}>0.05$ ) (Fig. 5). At $20^{\circ} \mathrm{C}$, in contrast, the specific activity of AP tended to decline with increasing $P_{C O}$ and that for trypsin was significantly lower at high $P^{\circ} \mathrm{CO}_{2}$ (ANOVA, $\mathrm{p}=0.009$ ). Indeed, the specific activity of trypsin in fish at $+1100 \mathrm{PCO}_{2}$ at $20^{\circ} \mathrm{C}$ was $\approx 70 \%$ that of fish in the ambient treatment (Fig. $5 \mathrm{~B}$ ).

\section{Discussion}

Knowledge on the combined effect of multiple stressors on the ecology of species and communities is still relatively scarce ${ }^{4,27}$ and there remains an urgent need to conduct experiments incorporating such interactions. Ocean acidification and warming (OAW) appears to induce a variety of responses in well-fed marine organisms ${ }^{9}$. The results of the present study suggest that different responses may have been observed in those studies if restricted feeding levels had been employed. In the present study, although no differences were observed in sea bass growth after nearly one year of rearing under OAW, obvious and significant differences in various aspects of growth physiology were observed due to OA when restricted feeding levels were applied in the feeding-growth trials.

Although the effect of OA on food intake and growth of marine organisms appears to be taxon-, speciesand life stage-specific, the results of the growing number of studies suggest that potentially deleterious effects of OA may be offset if ample food is available ${ }^{28,29}$. In calcifying organisms, for instance, it has been shown that food supply modulated the impact of low $\mathrm{pH}$ on growth ${ }^{17,28,29}$. Along that line, work on the eastern oyster 


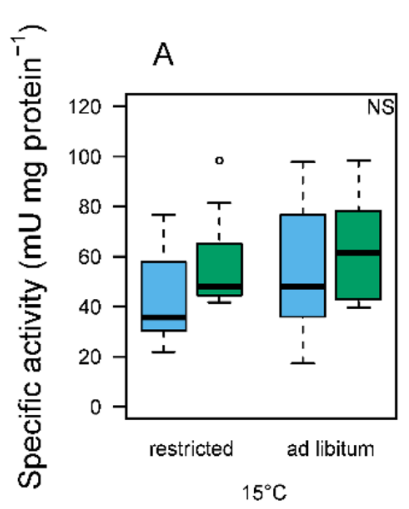

B

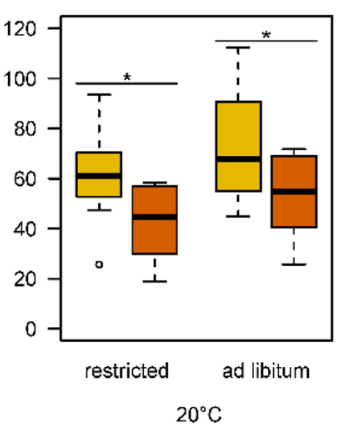

Trypsin

C

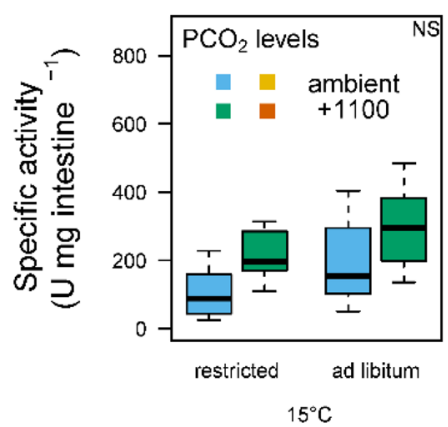

D

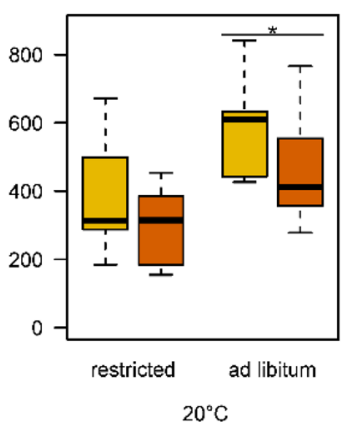

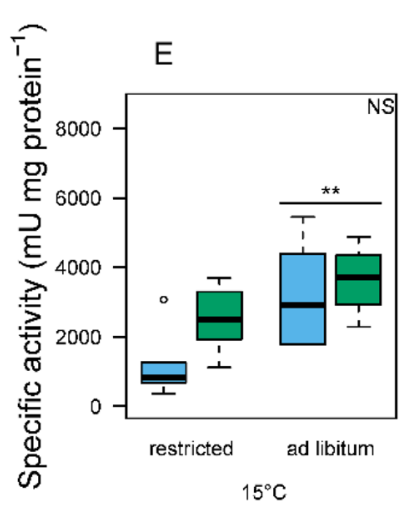

Alkaline phosphatase

$\mathrm{F}$

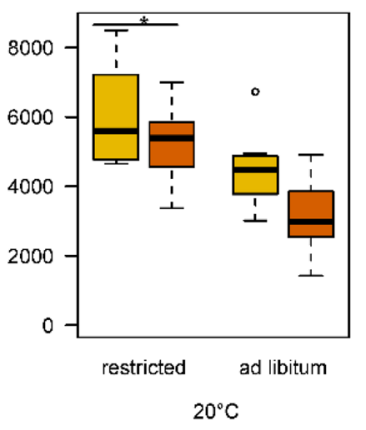

$\mathrm{G}$

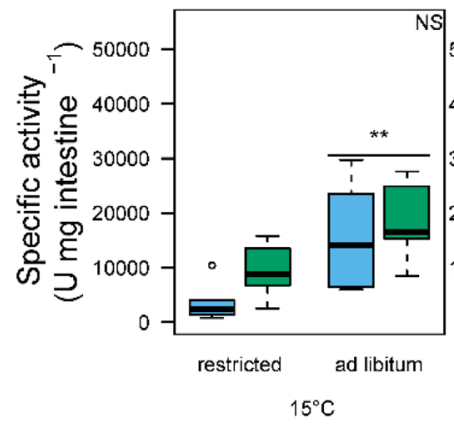

$\mathrm{H}$

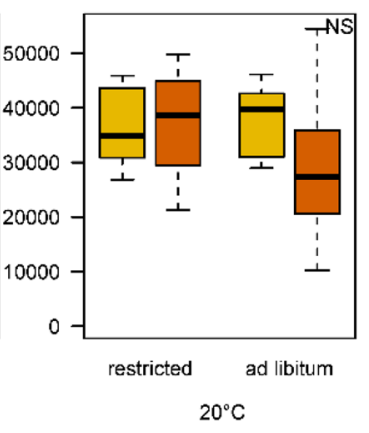

Figure 5. Box and whisker plots $(n=8)$ of specific activities of digestive enzymes of fish reared at two temperatures according to $\mathrm{PCO}_{2}$ levels and feeding levels ${ }^{94}$. Results are given in milli-units per mg of protein $\left(\mathrm{mU} \mathrm{mg}\right.$ protein $\left.^{-1}\right)$ for specific activity and in units per $\mathrm{mg}$ of intestine segment $\left(\mathrm{U} \mathrm{mg}\right.$ intestine $\left.\mathrm{e}^{-1}\right)$ for total activity. Stars denote significant differences (ANOVAs, $*<0.01, * *<0.001$ ). The whiskers denote the $10^{\text {th }}$ and $90^{\text {th }}$ percentiles, the box denotes the $25^{\text {th }}$ and $75^{\text {th }}$ percentiles, the median value is shown (horizontal line) as well as outliers (points).

(Crassostrea virginica) indicated that food availability partially offset the impacts of OA on larval growth and development ${ }^{16}$. Similarly, examination of the growth dynamics of polyps of two jellyfish species suggested that potential climate-driven changes in prey stoichiometry were more important in determining mass-gain than OA per $\mathrm{se}^{30}$. On the contrary, no differences were observed in the growth rate and skeletal development of cod (Gadus morhua) larvae reared at high $\mathrm{CO}_{2}$ and provided either a low or high food concentration ${ }^{22}$. To maintain similar rates of growth, however, those authors suggested that compensatory energy (re-)allocation occurred since larvae reared at low prey concentrations also displayed organ damage, especially to the liver. Although the growth performance of fish, particularly juveniles, is considered to be largely unaffected under high levels of $P_{C_{2}}{ }_{2}^{31,32}$, energy limitation imposed by restricted feeding may cause increased sensitivity to environmental stressors ${ }^{22,33}$.

Prior to the feeding trial, no difference in growth was observed regarding $\mathrm{PCO}_{2}$ treatment, while after the trial a difference in growth was observed between ambient and $+1100 \mathrm{PCO}_{2}$, at $20^{\circ} \mathrm{C}$. During long-term rearing, growth measurements were made on a subsample of fish from each tank while, in contrast, growth information was available for each (individual tagged) fish during the feeding trial. Moreover, while no mortalities occurred during the trials, $40 \%$ mortality occurred during rearing after larvae were transferred to juvenile tanks. European sea bass are known to be cannibalistic and it is possible that a larger number of small individuals were eaten in the $+1100 \mathrm{PCO}_{2}$ treatment during long-term rearing and cannibalism would have biased (increased) the growth rates calculated for surviving fish in this treatment ${ }^{34}$. The mean growth rate of ad libitum-fed individuals in this study was $1.4 \% \mathrm{~d}^{-1}$ at $20^{\circ} \mathrm{C}$ which is similar to growth rates $\left(0.6\right.$ to $\left.1.5 \% \mathrm{~d}^{-1}\right)$ reported for sea bass reared at comparable feeding levels and temperature ${ }^{35,36}$. Given that optimal temperatures for growth in juvenile sea bass were reported to be 22 to $24^{\circ} \mathrm{C}^{37}$, faster growth was expected at $20^{\circ} \mathrm{C}$ compared to $15^{\circ} \mathrm{C}$ in the present study. Although this was the case for fish in the ambient $\mathrm{PCO}_{2}$ treatment, mean growth rates of well-fed fish were similar at 20 and $15^{\circ} \mathrm{C}$ in the high $\mathrm{PCO}_{2}$ treatment.

The individuals used in the present study originated from wild-caught adults acclimatized and reared $(\sim 5$ years) in an aquaculture facility. The adults spawned at $13^{\circ} \mathrm{C}$ at a $\mathrm{pH}$ of 7.6 corresponding to our elevated condition of acidification. Adults were maintained in running seawater (a flow-through system) and not in a recirculating aquaculture system in which $\mathrm{PCO}_{2}$ levels could be relatively high. Previous studies have reported that the sensitivity of offspring to acidification might decrease with parental conditioning to high $\mathrm{PCO}_{2}{ }^{38-40}$. Therefore, the absence of differences in growth observed here at $15^{\circ} \mathrm{C}$ might be a consequence of transgenerational plasticity (TGP). This potential TGP, however, was absent at $20^{\circ} \mathrm{C}$. We are unaware of studies suggesting that TGP is 
expressed in only a narrow range of parental temperatures and OA conditions. Griffith and Gobler $(2017)^{41}$ highlighted that TGP is likely species-specific and, to our best knowledge, no studies have investigated TGP in sea bass.

Previous studies have indicated that $\mathrm{PCO}_{2}$ may alter rates of feeding ${ }^{42,43}$. For example, feeding and foraging activities of juvenile anemonefish (Amphiprion melanopus) were depressed at moderate levels of $\mathrm{PCO}_{2}(530$ $\mu \mathrm{atm})$ but enhanced at a higher level of $\mathrm{PCO}_{2}(960 \mu \mathrm{atm})^{42}$. On the contrary, reduced feeding by Chilean abalone (Concholepas concholepas) larvae at high $\mathrm{PCO}_{2}$ were reported ${ }^{43}$. Similarly, in the present study, daily ad libitum feeding rate was lower in fish in the high $\mathrm{PCO}_{2}$ treatment at $20^{\circ} \mathrm{C}$ (but not $15^{\circ} \mathrm{C}$ ) compared to the normocapnic treatment. Although not quantifyied, it was also clear that fish fed restricted level of food swam much less than the ad libitum fed fish (personal observation). Differences in SGR (specific growth rate) also existed between ambient and high $\mathrm{PCO}_{2}$ in fish maintained at a similar restricted ration level, suggesting that differences in growth were driven by differences in feed conversion efficiency (FCE) and not food consumption rate. The FCE depends on several, interacting factors such as feeding level and water temperature ${ }^{44-46}$. The relatively low FCE at $15^{\circ} \mathrm{C}$ (i.e. $\sim 0.5$ ) further highlights that this is a sub-optimal temperature for the growth of juvenile sea bass. The highest feed efficiency, however, occurs when fish are fed slightly below satiation ${ }^{47}$, which agrees with the pattern observed between the two ration levels at $20^{\circ} \mathrm{C}$ and ambient $P_{2}$. At $20^{\circ} \mathrm{C}$ and high $P \mathrm{CO}_{2}$, a drastic reduction in FCE was observed for fish on restricted rations compared to fish fed ad libitum. It is possible that high $P \mathrm{CO}_{2}$ increases maintenance or activity costs and/or reduces digestive capacity, and consequently reduces growth. Substantial levels of feeding providing sufficient energy income, however, could counteract those effects.

Values and changes in gastric $\mathrm{pH}$ as functions of stomach fullness and digestive stage have been well characterized in fish ${ }^{48-50}$. Although some teleosts constantly secrete acid to maintain low stomach $\mathrm{pH}$, even in the absence of food ${ }^{51}$, other teleosts, such as sea bass, only secrete acid in response to food ingestion. As a result, $\mathrm{pH}$ values in empty stomachs are generally less acidic $(>\mathrm{pH} 5.5)$ in these species ${ }^{52}$. Depending on the time since feeding, post-prandial $\mathrm{pH}$ values between 1.8 and 5.5 were measured in this study, which agrees well with values reported in a previous study on the same species ${ }^{53}$. Post-prandial changes in stomach $\mathrm{pH}$ observed in the present study were also similar to those reported for other temperate and sub-tropical teleosts such as gilthead sea bream (Sparus aurata) and the white sea bream (Diplodus sargus ${ }^{48,54}$, but were faster than those reported in a previous study on larger sea bass at $26^{\circ} \mathrm{C}^{53}$. After 3 or $4 \mathrm{hrs}$ post-feeding, there was no significant difference in stomach $\mathrm{pH}$ across the feeding and $\mathrm{PCO}_{2}$ treatment groups with mean $( \pm \mathrm{SE})$ values between $3.24(0.23)$ and 3.62(0.24) at 15 and $20^{\circ} \mathrm{C}$, respectively. This initial decrease in stomach $\mathrm{pH}$, due to the strong production of hydrochloric acid by the gastric glands, was sufficient to allow maximum activity of important proteases in the stomach (e.g. activity of pepsin is maximal at $\mathrm{pH}$ values of 1.5 to $4.0^{54}$ ). There were treatment-specific differences in the time needed for $\mathrm{pH}$ values to return to pre-feeding $(>5.5)$ levels. The post-prandial return of stomach $\mathrm{pH}$ was influenced by both meal size and $\mathrm{PCO}_{2}$. Ingesting large amounts of food leads to larger stomach distension ${ }^{53}$ that promotes stronger and more frequent peristaltic contraction and increased rates of food evacuation ${ }^{55}$. Results showed that, except for $20^{\circ} \mathrm{C}$ - ad libitum fish, high $\mathrm{PCO}_{2}$ led to a slower post-prandial return of stomach $\mathrm{pH}$ to more neutral, pre-feeding levels. Based on changes in oxygen consumption rate, a similar prolongation in digestion time was observed in Atlantic cod exposed to elevated $\mathrm{CO}_{2}{ }^{56}$. Tirsgaard et al. ${ }^{56}$ assumed that an extended digestion time and slower stomach clearance might lower food intake. In fish fed ad libitum at $20^{\circ} \mathrm{C}$, this slow return of stomach pH to pre-fed levels was observed in fish in the $+1100 \mu \mathrm{atm} \mathrm{PCO}_{2}$ treatment but not for fish in the ambient treatment, which may explain why the latter group consumed more food than the former group. As the alimentary bolus enters the intestine, a rapid buffering takes place through intense bicarbonate secretion into the intestine lumen ${ }^{57}$. We did not examine the time course of this process but it would be interesting to do so given the contribution of bicarbonate to maintaining acid-base homeostasis under hypercapnic conditions.

Higher values of enzyme activity were expected when feeding fish ad libitum rations. Surprisingly, at $20^{\circ} \mathrm{C}$, the specific activity of AP was higher when animals were feed-restricted. The potential preservation or increase in AP activity under dietary restriction is, to our knowledge, a unique finding in fish but similar results were reported in mice where restricted energy intake led to a significant increase in intestinal $\mathrm{AP}^{58}$. A second unexpected finding was the lack of a significant effect of feeding level (at both temperatures) on the specific activities of amylase and aminopeptidase N. A lower activity of both enzymes was expected with feed restriction ${ }^{59,60}$. The reason for this response is unknown.

Recent studies have shown that exposure to high $\mathrm{PCO}_{2}$ can trigger an increase in the secretion of intestinal bicarbonate $\left(\mathrm{HCO}_{3}^{-}\right)^{61}$ which, in turn, enhances AP activity ${ }^{62}$. In normocapnia, bicarbonate is secreted in the proximal intestine in response to low intestinal $\mathrm{pH}^{63}$. This secretion makes the intestine more alkaline, bringing $\mathrm{pH}$ closer to the optimum value for enzyme activity, such as $\mathrm{AP}^{64,65}$. Such regulation of $\mathrm{HCO}_{3}^{-}$secretion in response to low intestinal $\mathrm{pH}$ would explain why there was a tendency for higher enzymes activities in fish from the +1100 compared to the ambient $P \mathrm{CO}_{2}$ treatment at $15^{\circ} \mathrm{C}$. This tendency, however, was absent when individuals were reared at a warmer $\left(+5^{\circ} \mathrm{C}\right)$ temperature. Indeed, antagonistic effects $\left(\mathrm{PCO}_{2} \times\right.$ temperature $)$ were found for trypsin and AP activity. Thus, enzymatic activities were reduced at +1100 compared to ambient $P \mathrm{CO}_{2}$. Similar antagonistic patterns in digestive enzymes have been reported in newly born bamboo sharks (Chiloscyllium punctatum) experiencing $\mathrm{OAW}\left(+4{ }^{\circ} \mathrm{C} \mathrm{x} \sim 1400 \mu \text { atm } \mathrm{PCO}_{2}\right)^{66}$.

The decrease in the specific activity of AP and trypsin under hypercapnia observed in the present study are similar to those (AP) reported in Senegalese sole (Solea senegalensis) larvae ${ }^{67}$. Several studies have suggested that reduced activity of trypsin is an important mechanism limiting growth rate ${ }^{68,69}$. Trypsin is necessary for protein hydrolysis but the production of this enzyme requires the activation of machinery for cellular protein production. This activation represents another energetic demand ${ }^{70}$ in addition to the energy already invested to exchange ions and release bicarbonate. This additional energetic cost may be difficult to cover for fish persistently experiencing restricted feeding conditions. Such reductions in trypsin activity have been observed in juvenile sea bass exposed to hypoxia early in life ${ }^{24}$. It must be noted, however, that we measured the specific activity of trypsin in the lumen of the intestine, and that measurements in the pancreas would be necessary to verify this hypothesis. Moreover, 
reductions in digestive capacity could also result from direct damage to gut tissues as was demonstrated in young Atlantic cod reared under high $\mathrm{PCO}_{2}$ conditions ${ }^{71}$.

Overall, using a long-term exposure to OAW throughout the first year of life and examining the mechanisms of growth performance in a marine fish, the present study demonstrates how high feeding levels can reduce the impact of OAW. High $\mathrm{PCO}_{2}$ reduced the growth of juvenile sea bass reared at $20^{\circ} \mathrm{C}$ and these effects were exacerbated in fish fed restricted rations. Reduction in growth was not merely due to reduced food intake but also related to processes decreasing feed conversion efficiency such as digestive capacity (e.g. via reductions in the specific activity of digestive enzymes). Many of these deleterious impacts of $\mathrm{PCO}_{2}$ on sea bass were not observed at $15^{\circ} \mathrm{C}$, a sub-optimal temperature for the growth of juveniles of this species. In this study, the focus was on the impact of OAW combined with food availability. It is important to note that nutritional requirements of sea bass may differ under OA compared to ambient (present-day) conditions; consequently, fish on restricted rations may have not only experienced decreased caloric/energy intake but also an additional impact of poor nutrition. Changes in global nutritional requirements under OA would be interesting to examine in the context of energy allocation and digestive efficiency. Our study emphasizes the need to integrate different, ecologically relevant feeding levels in laboratory experiments assessing effect of OAW on marine organisms and suggests that previous studies that have used ad libitum feeding may underestimated the deleterious impacts of OAW.

\section{Materials and Methods}

The present work was performed within Ifremer-Centre de Bretagne facilities (agreement number: B29-212-05). Experiments were conducted according to the ethics and guideline of the French law and legislated by the local ethics committee (Comité d'Ethique Finistérien en Experimentation Animal, CEFEA, registering code C2EA-74) (Authorization APAFIS 4341.03, permit number 2016120211505680.v3).

Animals and experimental conditions. Water parameters. Sea bass used in the present experiments were reared since 3 days post-hatch $(\mathrm{dph})$, under one of 4 different $\mathrm{OAW}$ treatments including two different $\mathrm{PCO}_{2}$ levels (ambient and high $(+1100)$ ) and two thermal treatments $\left(15^{\circ} \mathrm{C}\right.$ and $\left.20^{\circ} \mathrm{C}\right)$. The ambient $P \mathrm{CO}_{2}$ was approx. $650 \mu \mathrm{atm}$. This is equal to today's situation for coastal waters of Brittany (Cameron and Iwama, 1987; Pimentel et al. ${ }^{33}$ ) where, in 2014, the annual mean $\mathrm{PCO}_{2}$ level was $603 \mu \mathrm{atm}$ (range 284-888 $\mu \mathrm{atm}$ ) in the Bay of Brest (Salt et al. 20167). The IPCC Representative Concentration Pathway (RCP) 8.5 scenario projected an increase of $\sim 500 \mu \mathrm{atm}$ above current values by the end of the century (IPCC, 2014 ${ }^{7}$ ). The $P \mathrm{CO}_{2}$ level in coastal areas and estuaries, habitats where sea bass juveniles and adults are encountered, however, is much higher ${ }^{72,73}$ ). In these shallow water coastal systems, $P C O_{2}$ levels often above $2000 \mu$ atm have been reported ${ }^{74,75}$. In accordance with these and additional $P_{C O}$ levels in European estuaries reported by Frankignoulle et al. ${ }^{76}$, the second treatment was fixed at $+1100 \mu$ atm above the ambient level (labelled +1100 , approx. $1700 \mu$ atm). The $15^{\circ} \mathrm{C}$ treatment included larval rearing at $15^{\circ} \mathrm{C}$ while juveniles experienced naturally fluctuating thermal conditions between 15 and $18^{\circ} \mathrm{C}$ (natural, seasonal differences reflecting ambient summer conditions in the Bay of Brest ${ }^{77,78}$, http://marc. ifremer.fr/en/results/temperatureand_salinity/mars3dchannel_bay_of_biscay_mode/(typevisu)/map/(zoneid)/ sudbzh\#appTop]). The $20^{\circ} \mathrm{C}$ treatment included larval rearing at $20^{\circ} \mathrm{C}$ while juveniles experienced 20 to $23^{\circ} \mathrm{C}$ $\left(5^{\circ} \mathrm{C}\right.$ increase relative to ambient temperature). The $5^{\circ} \mathrm{C}$ increased was defined based of the 'business-as-usual' (RCP 8.5) scenario as predicted by the Global Climate Models (GCMs) by 2100 (IPCC, $2007^{79}$ ). Constant temperature were applied for the larval stage which experience relatively stable temperature offshore while juveniles reach the estuaries in the late spring and are then exposed to seasonal change in temperature ${ }^{80,81}$.

Sea water was pumped in from the Bay of Brest from a depth of $20 \mathrm{~m}$ approximately $500 \mathrm{~m}$ from the coastline, passed through a sand filter $(\sim 500 \mu \mathrm{m})$, heated (tungsten, Plate Heat Exchanger, Vicarb, Sweden), degassed using a column, filtered using a $2 \mu \mathrm{m}$ membrane and finally UV sterilized (PZ50, 75 W, Ocene, France) assuring high water quality. Replicate treatment tanks ( $n=3$ for larval rearing and $n=2$ for juveniles rearing) were supplied with sea water via header tanks where water $\mathrm{PCO}_{2}$ was controlled using IKS Aquastar system (IKS Computer Systeme $\mathrm{GmbH}$, Germany). This system continuously measured water $\mathrm{pH}$ and was equipped with a solenoid valve that regulated the flow of $\mathrm{CO}_{2}$ from the gas cylinder using feedback from the $\mathrm{pH}$ electrode. The valve was turned on and off according to the electrode measurement. This valve, therefore, controlled the amount of $\mathrm{CO}_{2}$ injected in the water flowing through the header tank into the fish rearing tank (flow rate: $0.18 \mathrm{~L} \mathrm{~min}^{-1}$, corresponding to a water exchange of $30 \%$ per hour). Temperature and $\mathrm{pH}$ were checked ((WTW $3110 \mathrm{pH}$ meter, Xylem Analytics Germany, Weilheim, Germany; with electrode: WTW Sentix 41, NIST scale) each morning before feeding. The $\mathrm{pH}$ meter as well as the IKS Aquastar system were calibrated daily with NIST certified WTW technical buffers $\mathrm{pH}$ 4.01 and pH 7.00 (Xylem Analytics Germany, Weilheim, Germany). Total alkalinity was measured once a week following the protocol of Anderson \& Robinson ${ }^{82}$ and Strickland \& Parsons ${ }^{83}: 50 \mathrm{ml}$ of filtered tank water $(200 \mu \mathrm{m}$ nylon mesh) were mixed with $15 \mathrm{ml} \mathrm{HCl}(0.01 \mathrm{M})$ and $\mathrm{pH}$ was measured immediately. Total alkalinity was then calculated with the following formula:

$$
T A=\frac{V_{H C l} \cdot c_{H C l}}{V_{\text {sample }}}-\frac{\left(V_{H C l}+V_{\text {sample }}\right)}{V_{\text {sample }}} \cdot \frac{\left\{H^{+}\right\}}{\gamma_{H^{+}}}\left[\frac{m o l}{l}\right]
$$

With: TA - total alkalinity [mol * $\left.\mathrm{l}^{-1}\right], \mathrm{V}_{\mathrm{HCl}}$ - volume $\mathrm{HCl}[\mathrm{l}], \mathrm{c}_{\mathrm{HCl}}$ - concentration $\mathrm{HCl}\left[\mathrm{mol}^{*} \mathrm{l}^{-1}\right], \mathrm{V}_{\text {sample }}$ - volume of sample [1], $\mathrm{H}^{+}-$hydrogen activity $\left(10^{-\mathrm{pH}}\right), \gamma^{\mathrm{H}+}-$ hydrogen activity coefficient (here $\left.\gamma^{\mathrm{H}+}=0.758\right)$.

The Microsoft Excel macro CO2sys ${ }^{84}$ was used to calculate seawater carbonate chemistry, the constants after Mehrbach et al. ${ }^{85}$ (as cited in CO2sys) refit by Dickson \& Millero ${ }^{86}$, were employed. Using the CO2sys, daily $\mathrm{pH}$ (NIST) values were c converted to $\mathrm{pH}$ (free) values. Oxygen saturation (WTW Oxi 340, Xylem Analytics Germany, Weilheim, Germany) and salinity (WTW LF325, Xylem Analytics Germany, Weilheim, Germany) were measured once a week together with total alkalinity, from juvenile stage onwards, see all water parameters in Table 1. 


\begin{tabular}{|l|l|l|l|l|l|c|}
\hline Treatment & $\mathbf{p H}[$ free scale $]$ & Temp. $\left[{ }^{\circ} \mathbf{C}\right]$ & Salinity $[\mathbf{p s u}]$ & $\mathbf{O} 2[\%$ airsat. & TA $\left[\mathbf{m o l ~}^{-1}\right]$ & $\mathbf{P C O}_{2}[\boldsymbol{\mu a t m}]$ \\
\hline $\mathrm{L} 15^{\circ} \mathrm{C} \mathrm{A}$ & $7.95 \pm 0.01$ & $15.3 \pm 0.0$ & $33.0 \pm 0.1$ & - & $2364 \pm 17$ & $656 \pm 16$ \\
\hline $\begin{array}{l}\mathrm{L} 15^{\circ} \mathrm{C} \\
+1100\end{array}$ & $7.58 \pm 0.00$ & $15.3 \pm 0.0$ & $33.0 \pm 0.1$ & - & $2394 \pm 26$ & $1682 \pm 26$ \\
\hline $\mathrm{L} 20^{\circ} \mathrm{C} \mathrm{A}$ & $7.88 \pm 0.01$ & $20.0 \pm 0.1$ & $33.1 \pm 0.1$ & - & $2369 \pm 21$ & $832 \pm 13$ \\
\hline $\begin{array}{l}\mathrm{L} 20^{\circ} \mathrm{C} \\
+1100\end{array}$ & $7.60 \pm 0.01$ & $20.0 \pm 0.1$ & $33.1 \pm 0.1$ & - & $2380 \pm 23$ & $1672 \pm 33$ \\
\hline $\mathrm{J} 15^{\circ} \mathrm{C} \mathrm{A}$ & $7.97 \pm 0.01$ & $16.0 \pm 0.2$ & $34.2 \pm 0.1$ & $90.9 \pm 0.5$ & $2396 \pm 18$ & $655 \pm 18$ \\
\hline $\mathrm{J} 15^{\circ} \mathrm{C}+1100$ & $7.55 \pm 0.01$ & $16.1 \pm 0.2$ & $34.2 \pm 0.1$ & $90.9 \pm 0.6$ & $2399 \pm 19$ & $1841 \pm 40$ \\
\hline $\mathrm{J} 20^{\circ} \mathrm{C} \mathrm{A}$ & $7.92 \pm 0.01$ & $21.9 \pm 0.2$ & $35.0 \pm 0.2$ & $90.2 \pm 0.9$ & $2418 \pm 12$ & $788 \pm 22$ \\
\hline $\mathrm{J} 20^{\circ} \mathrm{C}+1100$ & $7.59 \pm 0.01$ & $21.9 \pm 0.2$ & $35.0 \pm 0.2$ & $91.3 \pm 0.6$ & $2423 \pm 12$ & $1808 \pm 65$ \\
\hline $\mathrm{SW} 15^{\circ} \mathrm{C}$ & $8.05 \pm 0.01$ & $14.5 \pm 0.5$ & $33.0 \pm 0.2$ & $101.2 \pm 0.6$ & $2434 \pm 21$ & $522 \pm 18$ \\
\hline $\mathrm{SW} 20^{\circ} \mathrm{C}$ & $7.95 \pm 0.02$ & $21.2 \pm 0.4$ & $32.7 \pm 0.1$ & $102.3 \pm 1.4$ & $2433 \pm 28$ & $723 \pm 33$ \\
\hline
\end{tabular}

Table 1. Water parameters during the larval and juvenile phase of batch 2016 : Larval period at $15^{\circ} \mathrm{C}(\mathrm{L}$ $15^{\circ} \mathrm{C}$ ) from 3 to $60 \mathrm{dph}$ and $20^{\circ} \mathrm{C}\left(\mathrm{L} 20^{\circ} \mathrm{C}\right)$ from 3 to $46 \mathrm{dph}$. Juvenile period at $15^{\circ} \mathrm{C}\left(\mathrm{J} 15^{\circ} \mathrm{C}\right)$ from 61 to $387 \mathrm{dph}$ and $20^{\circ} \mathrm{C}\left(\mathrm{J} 20^{\circ} \mathrm{C}\right)$ from 47 to $280 \mathrm{dph}$. Mean $( \pm \mathrm{SE})$ values are provided over all replicate tanks per treatment. Temperature (Temp.) and $\mathrm{pH}$ (NIST) were measured daily and converted to $\mathrm{pH}$ (free). Salinity, total alkalinity (TA) and oxygen concentration (O2, juveniles only) were measured weekly and $\mathrm{PCO}_{2}$ was calculated with CO2sys. Sea water (SW) measurements were conducted during 2017 and 2018. A $=A$ mbient $P C C_{2}$, $+1100=$ ambient $+1100 \mu$ atm $P_{2}$.

Larval and juvenile rearing. Larvae used in this experiment were the progeny of wild brood stock fish caught off Morbihan, France, and kept at an aquaculture facility (Aquastream, Ploemeur-Lorient, France). Four females (mean mass $4.5 \mathrm{~kg}$ ) were crossed with ten males (mean mass $2.4 \mathrm{~kg}$ ), which spawned naturally using photothermal manipulation. At $2 \mathrm{dph}$, larvae were transferred to the Ifremer-Centre de Bretagne. Larval rearing was performed in a temperature-controlled room using black, 35-L tanks. Rapid acclimation to a new temperature (e.g. to $20^{\circ} \mathrm{C}$ ), feeding regime and photoperiod was implemented as described by Gourtay et al. ${ }^{87}$ until the juvenile stage. Juvenile were moved to 670 - $\mathrm{L}$ tanks at $50 \mathrm{dph}$ and $65 \mathrm{dph}$ for fish reared at $20^{\circ} \mathrm{C}$ and $15^{\circ} \mathrm{C}$, respectively. There were randomly allocated to two treatment tanks. Having only two replicates limited our ability to estimate variation but dividing the fish randomly will remove any potential tank effect during larval rearing. Prior to trials, during the rearing of juveniles, mortality was between 24.8 and $43.4 \%$ per tank. Juveniles were fed ad libitum daily rations of commercial fish food (Neo Start, Le Gouessant, Lamballe, France) using automatic feeders. Photoperiod was adjusted to natural conditions once a week. The tanks were cleaned daily after $\mathrm{pH}$-measurements. Water flow rates maintained oxygen saturation levels above $90 \%$.

Feeding-growth trial. At 8 and 11 months post-hatch, for the $20^{\circ} \mathrm{C}$ and the $15^{\circ} \mathrm{C}$ rearing condition, respectively, fish between 10 and $100 \mathrm{~g}$ were selected for the feeding trials (about $90 \%$ of all juveniles). Fish were subcutaneously tagged (Passive integrated transponder; Pit-tag) for individual identification and randomly allocated among 12 indoor, 500-L tanks supplied with filtered and aerated natural seawater. Fish were excluded that i) were $<10 \mathrm{~g}$ since these were too small to be tagged, ii) had any morphological deformities, and iii) were $>100 \mathrm{~g}$. Fish were allocated (maintaining $\mathrm{PCO}_{2}$ history) so that there was a similar mean and variance of fish sizes and, hence, similar total biomass in each replicate tank (mean \pm SE; $1876.72 \pm 30.94 \mathrm{~g}(\sim 33 \mathrm{fish})$ and $1287.30 \pm 14.87 \mathrm{~g}$ ( $\sim 35$ fish), for $20^{\circ} \mathrm{C}$ and $15^{\circ} \mathrm{C}$ trials, respectively). Feeding-growth trials commenced after a $>7$-day acclimation period to the tanks (Fig. S1). Juveniles were 303 and $399 \mathrm{dph}$ at the start of the $20^{\circ} \mathrm{C}$ and $15^{\circ} \mathrm{C}$ trials, respectively, and had a mean $( \pm S E)$ wet mass of $52.13(0.62)$ and $31.08(0.42) \mathrm{g}$, respectively. Three replicate tanks for each $\mathrm{PCO}_{2}$ treatment were randomly assigned to ad libitum and "restricted" feeding treatments. Feed was administrated during daylight hours. In the ad libitum treatment, fish were fed three times a day (at 09:00, 13:00 and 17:00). A known initial mass of food $\left(30\right.$ and $50 \mathrm{~g}$ for 15 and $20^{\circ} \mathrm{C}$ fish, respectively) was partially distributed to each tank three times a day (09:00, 13:00 and 17:00). Food was delivered by hand making sure that no food was left uneaten. The mass of food not distributed to each tank was determined. The mass fed (consumed by fish) was the difference between the final and initial masses of feed for a tank on that day. The mean value for the three replicate ad libitum tanks was determined and $25 \%$ of that value was set as the ration for the restricted feeding group the next day (starting at 9:00 and distributed using an automatic feeder). The restricted ration was fed using an automatic feeder starting at 9:00. Food consumption of ad libitum-fed fish showed daily variation (reported in the Fig. S5). The 20 and $15^{\circ} \mathrm{C}$ trial lasted 18 and 38 days, respectively.

At the start and end of the trial, every fish was slightly anesthetized with tricaine methanesulfonate (MS-222; dose adapted to water temperature and fish mass, typically $0.2 \mathrm{gl}^{-1}$ ) and wet mass (WM) was measured (Cubis MSE12201S-000-D0, Sartorius, Germany; $\mathrm{d}=0.1 \mathrm{~g}$ ). Specific growth rate (SGR, $\% \mathrm{~d}^{-1}$ ) and feed conversion efficiency (FCE, \%) were calculated according to the following formulas:

$$
\begin{aligned}
& \text { SGR }=100\left(\ln \left[\mathrm{WM}_{\text {final }}\right]-\ln \left[\mathrm{WM}_{\text {initial }}\right]\right) / \text { Number of Days of Feeding } \\
& \text { FCE }=\text { Biomassgain }(\mathrm{g}) / \text { Total Mass of Food Consumed in the Tank }(\mathrm{g})
\end{aligned}
$$

With Biomassgain corresponding to the final wet biomass minus initial wet biomass in the tank. 
Determination of digestive enzymes. Fish were sampled for digestive enzymes twice, once one day before the start of the trial (after the acclimation period) and one week after final weighing, while keeping them on the two rations levels (experimental day 29 at $20^{\circ} \mathrm{C}$, and 49 at $15^{\circ} \mathrm{C}$, see Fig. S1). Fish were starved for $48 \mathrm{~h}$ prior to both samplings and each time 8 to 9 individuals were randomly sampled per treatment. Fish were dissected on ice, the abdominal cavity was opened and the intestine was separated from the rest of the gut. For each fish, the mucosa of the digestive track was collected by scraping the anterior of the intestine, put directly in $1.5-\mathrm{ml}$ microtubes and stored at $-80^{\circ} \mathrm{C}$. To purify brush border membranes, intestinal mucosa was homogenized according to a method described by Crane et al..$^{88}$. This included homogenizing the intestinal mucosa for $20 \mathrm{~s}$ (ultra turax, Poltron PT2100, Kinematica AG, Switzerland) at maximum speed with a mix solution of Mannitol and Tris- $\mathrm{HCl}$, collecting $1 \mathrm{ml}$ of homogenate, adding $\mathrm{CaCl}_{2}$, centrifuging at 9,000 $\times \mathrm{g}$ for $10 \mathrm{~min}$, removing the supernatant and centrifuging at 3,400 $\times \mathrm{g}$ for $20 \mathrm{~min}$. The pellet was resuspended in Tris-Hepesbuffer and used for enzymatic assays. Trypsin and amylase activities were assayed according to Holm et al..$^{89}$ and Métais \& Bieth ${ }^{90}$, respectively. Enzymes of the brush border membrane, alkaline phosphatase (AP) and aminopeptidase $\mathrm{N}$ were assayed according to Bessey et al..$^{91}$ and Maroux et al.${ }^{92}$, respectively. Proteins were determined according to the Bradford ${ }^{93}$ procedure. Enzyme activities were expressed in milliunits of specific activity (i.e. $\mathrm{mU}$ mg protein ${ }^{-1}$ ) and units of total activity (i.e. $\mathrm{U}_{\text {segment }}{ }^{-1}$ ).

Determination of kinetic of stomach pH following ingestion. On trial day 35 at $20^{\circ} \mathrm{C}$ and 55 at $15^{\circ} \mathrm{C}$, fish were fasted for 48 -h and then re-fed based on their treatment. Stomach $\mathrm{pH}$ was measured at the end of the fasting period, $30 \mathrm{~min}$ post feeding and then regularly during the digestion process (see Fig. S1). For each measurement, 8 individuals were randomly sampled within each replicate tank, anaesthetized with MS-222, and the stomach immediately removed. A pH electrode (WTW Inolab 720 pH meter, Xylem Analytics Germany, Weilheim, Germany) was then inserted and maintained in the anterior portion of the stomach. While dissections took place on ice, the $\mathrm{pH}$ was measured at room temperature and the electrode was calibrated every three measurements.

Statistical analysis. Normality for SGR data was first assumed according to the central limit theorem and verified visually via a q-plot of the raw data and residuals. Differences in SGR, specific ad libitum food consumption rate and FCE were tested using two-way ANOVAs. The overall effect of temperature and $P \mathrm{O}_{2}$ level on daily total food intake was examined using a two-way, nested ANOVA. Significant ANOVAs were followed by a Student-Newman-Keuls multiple comparison test to determine differences among experimental groups. At each temperature, a linear mixed-effects model (LME models) was used to predict changes in the mean and variance (and, thus, the dynamics) of stomach $\mathrm{pH}$ in juvenile sea bass according to ration and $\mathrm{PCO}_{2}$ treatments (reported in Table S1 and S2). Time was considered a random effect and $\mathrm{PCO}_{2}$ level and feeding level were fixed effects. At each temperatures, the predictions of the LME model for stomach pH were compared across treatments $\left(P \mathrm{O}_{2}\right.$ level, feeding level) and sampling times with an ANOVA followed by a Tukey test. Differences were considered significant at $\alpha=0.05$. Differences in the magnitude of the initial decline in stomach $\mathrm{pH}$ among the four treatment groups ( 2 feeding levels, $2 \mathrm{PCO}_{2}$ levels) at each sampling time within temperature (e.g. after 3 or 8 hrs at $15^{\circ} \mathrm{C}$; 4 or $9 \mathrm{hrs}$ at $20^{\circ} \mathrm{C}$ ) were assessed with a Kruskal-Wallis test. Differences were considered significant at $\alpha=0.05$. Enzymes activities (specific and total), of each enzymes, were first tested for a temperature effect via a one-way ANOVA. Differences between $\mathrm{PCO}_{2}$ and feeding treatments were masked by high response of activity found at $20^{\circ} \mathrm{C}$, so potential effects were test separately between the two temperatures using two-way ANOVAs. Differences in enzyme activity were considered significant at $\alpha=0.01$. All statistical analyses were performed with R (ver.3.3.3; R Development Core Team).

Received: 21 May 2019; Accepted: 16 January 2020;

Published online: 11 February 2020

\section{References}

1. Breitburg, D. L. et al. Understanding Effects of Multiple Stressors: Ideas and Challenges. in Successes, Limitations, and Frontiers in Ecosystem Science (eds. Pace, M. L. \& Groffman, P. M.) 416-431, https://doi.org/10.1007/978-1-4612-1724-4_17, (Springer New York, 1998)

2. Frost, T. M. et al. Multiple stresses from a single agent: Diverse responses to the experimental acidification of Little Rock Lake, Wisconsin. Limnol. Oceanogr. 44, 11 (1999).

3. Schindler, D. W. The Cumulative Effects of Climate Warming and Other Human Stresses on Canadian Freshwaters in the New Millennium. (2001) Available at: https://www.researchgate.net/publication/255649878_The_Cumulative_Effects_of_Climate_ Warming_and_Other_Human_Stresses_on_Canadian_Freshwaters_in_the_New_Millennium. (Accessed: 22nd August 2019).

4. Hodgson, E. E. \& Halpern, B. S. Investigating cumulative effects across ecological scales: Cumulative Impacts Across Scales. Conserv. Biol. https://doi.org/10.1111/cobi.13125 (2018).

5. Vinebrooke, R. D. et al. Impacts of multiple stressors on biodiversity and ecosystem functioning: the role of species co-tolerance. Oikos 104, 451-457 (2004).

6. Meehl, G. A. et al. Global climate projections. (2007)

7. Climate Change 2014: Synthesis Report of the IPCC Fifth Assessment Report (AR5) | weADAPT. Available at: https://www.weadapt. org/knowledgebase/national-adaptation-planning/climate-change-2014-synthesis-report. (Accessed: 27th February 2019).

8. Doney, S. et al. Climate Change Impacts on Marine Ecosystems. vol. 4 (2012).

9. Harvey, B. P., Gwynn-Jones, D. \& Moore, P. J. Meta-analysis reveals complex marine biological responses to the interactive effects of ocean acidification and warming. Ecol. Evol. 3, 1016-1030 (2013).

10. Lefevre, S. Are global warming and ocean acidification conspiring against marine ectotherms? A meta-analysis of the respiratory effects of elevated temperature, high $\mathrm{CO}_{2}$ and their interaction. Conserv. Physiol. 4, cow009 (2016).

11. Kroeker, K. J. et al. Impacts of ocean acidification on marine organisms: quantifying sensitivities and interaction with warming. Glob. Change Biol. 19, 1884-1896 (2013).

12. Pope, E. C. et al. European sea bass, Dicentrarchus labrax, in a changing ocean. Biogeosciences 11, 2519-2530 (2014). 
13. Pimentel, M. S. et al. Defective skeletogenesis and oversized otoliths in fish early stages in a changing ocean. J. Exp. Biol. 217, 2062-2070 (2014).

14. McCulloch, M., Falter, J., Trotter, J. \& Montagna, P. Coral resilience to ocean acidification and global warming through pH upregulation. Nat. Clim. Change 2, 623-627 (2012).

15. Cohen, A. \& Michael, H. Why Corals Care About Ocean Acidification: Uncovering the Mechanism. Oceanography 22 (2009).

16. Hettinger, A. et al. The influence of food supply on the response of Olympia oyster larvae to ocean acidification. Biogeosciences 10, 6629-6638 (2013).

17. Thomsen, J., Casties, I., Pansch, C., Körtzinger, A. \& Melzner, F. Food availability outweighs ocean acidification effects in juvenile Mytilus edulis: laboratory and field experiments. Glob. Change Biol. 19, 1017-1027 (2013).

18. Towle, E. K., Enochs, I. C. \& Langdon, C. Threatened Caribbean Coral Is Able to Mitigate the Adverse Effects of Ocean Acidification on Calcification by Increasing Feeding Rate. PLoS ONE 10, e0123394 (2015).

19. Gobler, C. J., Merlo, L. R., Morrell, B. K. \& Griffith, A. W. Temperature, Acidification, and Food Supply Interact to Negatively Affect the Growth and Survival of the Forage Fish, Menidia beryllina (Inland Silverside), and Cyprinodon variegatus (Sheepshead Minnow). Front. Mar. Sci. $\mathbf{5}$ (2018).

20. Hurst, T. P., Laurel, B. J., Hanneman, E., Haines, S. A. \& Ottmar, M. L. Elevated $\mathrm{CO}_{2}$ does not exacerbate nutritional stress in larvae of a Pacific flatfish. Fish. Oceanogr 26, 336-349 (2017).

21. Sswat, M. et al. Food web changes under ocean acidification promote herring larvae survival. Nat. Ecol. Evol. 2 (2018).

22. Stiasny, M. H. et al. Divergent responses of Atlantic cod to ocean acidification and food limitation. Glob. Change Biol. 25, 839-849 (2019).

23. Cahu, C. L. \& Infante, J. L. Z. Early weaning of sea bass (Dicentrarchus labrax) larvae with a compound diet: Effect on digestive enzymes. Comp. Biochem. Physiol. A Physiol. 109, 213-222 (1994).

24. Zambonino-Infante, J. L. et al. An early life hypoxia event has a long-term impact on protein digestion and growth in juvenile European sea bass. J. Exp. Biol. 220, 1846-1851 (2017).

25. Stumpp, M. et al. Digestion in sea urchin larvae impaired under ocean acidification. Nat. Clim. Change 3, 1044-1049 (2013).

26. Strobel, A. et al. Metabolic shifts in the Antarctic fish Notothenia rossii in response to rising temperature and $P \mathrm{CO}_{2}$. Front. Zool. 9 , 28 (2012).

27. Gunderson, A. R., Armstrong, E. J. \& Stillman, J. H. Multiple Stressors in a Changing World: The Need for an Improved Perspective on Physiological Responses to the Dynamic Marine Environment. Annu. Rev. Mar. Sci 8, 357-378 (2016).

28. Melzner, F. et al. Food Supply and Seawater $p \mathrm{CO}_{2}$ Impact Calcification and Internal Shell Dissolution in the Blue Mussel Mytilus edulis. PLoS ONE 6, e24223 (2011).

29. Ramajo, L. et al. Food supply confers calcifiers resistance to ocean acidification. Sci. Rep. 6 (2016).

30. Lesniowski, T. J. et al. Effects of food and $\mathrm{CO}_{2}$ on growth dynamics of polyps of two scyphozoan species (Cyanea capillata and Chrysaora hysoscella). Mar. Biol. 162, 1371-1382 (2015).

31. Cattano, C., Claudet, J., Domenici, P. \& Milazzo, M. Living in a high $\mathrm{CO}_{2}$ world: a global meta-analysis shows multiple traitmediated fish responses to ocean acidification. Ecol. Monogr. 88, 320-335 (2018).

32. Foss, A. et al. Effects of water reuse and stocking density on water quality, blood physiology and growth rate of juvenile cod (Gadus morhua). Aquaculture 256, 255-263 (2006).

33. Pimentel, M. S. et al. Foraging behaviour, swimming performance and malformations of early stages of commercially important fishes under ocean acidification and warming. Clim. Change 137, 495-509 (2016).

34. Hatziathanasiou, A. et al. Survival, growth and feeding in early life stages of European sea bass (Dicentrarchus labrax) intensively cultured under different stocking densities. Aquaculture 205, 89-102 (2002).

35. Benhaï, D. et al. Effect of size grading on sea bass (Dicentrarchus labrax) juvenile self-feeding behaviour, social structure and culture performance. Aquat. Living Resour. 24, 391-402 (2011).

36. Gardeur, J.-N., Lemarié, G., Coves, D. \& Boujard, T. Typology of individual growth in sea bass (Dicentrarchus labrax). Aquat. Living Resour 14, 223-231 (2001).

37. Claireaux, G. \& Lagardère, J.-P. Influence of temperature, oxygen and salinity on the metabolism of the European sea bass. J. Sea Res. 42, 157-168 (1999)

38. Munday, P. L. Transgenerational acclimation of fishes to climate change and ocean acidification. F1000Prime Rep. 6 (2014).

39. Murray, C., Malvezzi, A. J., Gobler, C. \& Baumann, H. Offspring sensitivity to ocean acidification changes seasonally in a coastal marine fish. Mar. Ecol. Prog. Ser. 504, 1-11 (2014).

40. Jarrold, M. D. \& Munday, P. L. Diel CO2 cycles and parental effects have similar benefits to growth of a coral reef fish under ocean acidification. Biol. Lett 15, 20180724 (2019).

41. Griffith, A. W. \& Gobler, C. J. Transgenerational exposure of North Atlantic bivalves to ocean acidification renders offspring more vulnerable to low pH and additional stressors. Sci. Rep 7, 11394 (2017).

42. Nowicki, J. P., Miller, G. M. \& Munday, P. L. Interactive effects of elevated temperature and $\mathrm{CO}_{2}$ on foraging behavior of juvenile coral reef fish. J. Exp. Mar. Biol. Ecol. 412, 46-51 (2012).

43. Vargas, C. A. et al. $\mathrm{CO}_{2}$-driven ocean acidification reduces larval feeding efficiency and changes food selectivity in the mollusk Concholepas concholepas. J. Plankton Res. 35, 1059-1068 (2013).

44. Buentello, J. A., Gatlin, D. M. \& Neill, W. H. Effects of water temperature and dissolved oxygen on daily feed consumption, feed utilization and growth of channel catfish (Ictalurus punctatus). Aquaculture 182, 339-352 (2000).

45. Handeland, S. O., Imsland, A. K. \& Stefansson, S. O. The effect of temperature and fish size on growth, feed intake, food conversion efficiency and stomach evacuation rate of Atlantic salmon post-smolts. Aquaculture 283, 36-42 (2008).

46. Imsland, A. K., Foss, A., Sparboe, L. O. \& Sigurdsson, S. The effect of temperature and fish size on growth and feed efficiency ratio of juvenile spotted wolffish Anarhichas minor. J. Fish Biol. 68, 1107-1122 (2006).

47. Zoccarato, I. et al. Differences in performance, flesh composition and water output quality in relation to density and feeding levels in rainbow trout, Oncorhynchus mykiss (Walbaum), farming. Aquac. Res. 25, 639-647 (1994).

48. Deguara, S., Jauncey, K. \& Agius, C. Enzyme activities and $\mathrm{pH}$ variations in the digestive tract of gilthead sea bream. J. Fish Biol. 62, 1033-1043 (2003).

49. Getachew, T. Stomach $\mathrm{pH}$, feeding rhythm and ingestion rate in Oreochromis niloticus L. (Pisces: Cichlidae) in Lake Awasa, Ethiopia. Hydrobiologia 174, 43-48 (1989).

50. Kużmina, V. V. Influence of age on digestive enzyme activity in some freshwater teleosts. Aquaculture 148, 25-37 (1996).

51. Bucking, C. \& Wood, C. M. The effect of postprandial changes in $\mathrm{pH}$ along the gastrointestinal tract on the distribution of ions between the solid and fluid phases of chyme in rainbow trout. Aquac. Nutr 15, 282-296 (2009).

52. Solovyev, M. \& Gisbert, E. Influence of time, storage temperature and freeze/thaw cycles on the activity of digestive enzymes from gilthead sea bream (Sparus aurata). Fish Physiol. Biochem. 42, 1383-1394 (2016).

53. Nikolopoulou, D. et al. Patterns of gastric evacuation, digesta characteristics and $\mathrm{pH}$ changes along the gastrointestinal tract of gilthead sea bream (Sparus aurata L.) and European sea bass (Dicentrarchus labrax L.). Comp. Biochem. Physiol. A. Mol. Integr. Physiol. 158, 406-414 (2011). 
54. Yúfera, M., Moyano, F. J., Astola, A., Pousão-Ferreira, P. \& Martínez-Rodríguez, G. Acidic Digestion in a Teleost: Postprandial and Circadian Pattern of Gastric pH, Pepsin Activity, and Pepsinogen and Proton Pump mRNAs Expression. PLoS ONE 7, e33687 (2012).

55. Jobling, M. Mathematical models of gastric emptying and the estimation of daily rates of food consumption for fish. J. Fish Biol. 19, 245-257 (1981).

56. Tirsgaard, B., Moran, D. \& Steffensen, J. F. Prolonged SDA and reduced digestive efficiency under elevated $\mathrm{CO}_{2}$ may explain reduced growth in Atlantic cod (Gadus morhua). Aquat. Toxicol. Amst. Neth. 158, 171-180 (2015).

57. Taylor, J. R. \& Grosell, M. Feeding and osmoregulation: dual function of the marine teleost intestine. J. Exp. Biol. 209, 2939-2951 (2006).

58. Dao, M. L., Shao, R., Risley, J. \& Good, R. A. Influence of chronic energy intake restriction on intestinal alkaline phosphatase in C3H/Bi mice and autoimmuneprone MRL/lpr,lpr mice. J. Nutr 119, 2017-2022 (1989).

59. Cyrino, J. E. P., Bureau, D. P. \& Kapoor, B. G. Feeding and digestive functions of fishes. (Enfield, N.H.: Science Publishers, 2008).

60. Infante, J. L. Z., Cahu, C. L., Pères, A., Quazuguel, P. \& Le Gall, M. M. Sea bass (Dicentrarchus labrax) larvae fed different Artemia rations: growth, pancreas enzymatic response and development of digestive functions. Aquaculture 139, 129-138 (1996).

61. Heuer, R. M., Esbaugh, A. J. \& Grosell, M. Ocean acidification leads to counterproductive intestinal base loss in the gulf toadfish (Opsanus beta). Physiol. Biochem. Zool. 85, 450-459 (2012).

62. Akiba, Y., Mizumori, M., Guth, P. H., Engel, E. \& Kaunitz, J. D. Duodenal brush border intestinal alkaline phosphatase activity affects bicarbonate secretion in rats. Am. J. Physiol. Gastrointest. Liver Physiol. 293, G1223-1233 (2007).

63. Gregório, S. F., Ruiz-Jarabo, I., Carvalho, E. M. \& Fuentes, J. Increased intestinal carbonate precipitate abundance in the sea bream (Sparus aurata L.) in response to ocean acidification. PLoS ONE 14, e0218473 (2019).

64. Fraisse, M., Woo, N. Y. S., Noaillac-Depeyre, J. \& Murat, J. C. Distribution pattern of digestive enzyme activities in the intestine of the catfish (Ameiurus nebulosus L.) and of the carp (Cyprinus carpio L.). Comp. Biochem. Physiol. A Physiol. 70, 443-446 (1981).

65. Lallès, J.-P. Intestinal alkaline phosphatase: multiple biological roles in maintenance of intestinal homeostasis and modulation by diet. Nutr. Rev 68, 323-332 (2010).

66. Rosa, R. et al. Deficit in digestive capabilities of bamboo shark early stages under climate change. Mar. Biol. 163, 60 (2016).

67. Pimentel, M. S. et al. Oxidative Stress and Digestive Enzyme Activity of Flatfish Larvae in a Changing Ocean. PLoS ONE 10 (2015).

68. Lemieux, H., Blier, P. \& Dutil, J.-D. Do digestive enzymes set a physiological limit on growth rate and food conversion efficiency in the Atlantic cod (Gadus morhua)? Fish Physiol. Biochem. 20, 293-303 (1999).

69. Rungruangsak-Torrissen, K., Moss, R., Andresen, L. H., Berg, A. \& Waagbø, R. Different expressions of trypsin and chymotrypsin in relation to growth in Atlantic salmon (Salmo salar L.). Fish Physiol. Biochem. 32, 7-23 (2006).

70. Lamarre, S. G. et al. Interrelationship Between Contractility, Protein Synthesis and Metabolism in Mantle of Juvenile Cuttlefish (Sepia officinalis). Front. Physiol. 10 (2019).

71. Frommel, A. et al. Severe tissue damage in Atlantic cod larvae under increasing ocean acidification. Nat. Clim. Change 2, 42-46 (2012).

72. Pickett, G. D. \& Pawson, M. G. Sea Bass: Biology. (Springer Science \& Business Media, 1994).

73. Lonthair, J., Ern, R. \& Esbaugh, A. J. The early life stages of an estuarine fish, the red drum (Sciaenops ocellatus), are tolerant to high

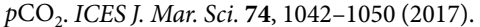

74. Wallace, R. B., Baumann, H., Grear, J. S., Aller, R. C. \& Gobler, C. J. Coastal ocean acidification: The other eutrophication problem. Estuar. Coast. Shelf Sci. 148, 1-13 (2014).

75. Melzner, F. et al. Future ocean acidification will be amplified by hypoxia in coastal habitats. Mar. Biol. 160, 1875-1888 (2013).

76. Frankignoulle, M. et al. Carbon Dioxide Emission from European Estuaries. Science 282, 434-436 (1998).

77. Chauvaud, L., Donval, A., Thouzeau, G., Paulet, Y.-M. \& Nézan, E. Variations in food intake of Pecten maximus (L.) from the Bay of Brest (France): Influence of environmental factors and phytoplankton species composition. Comptes Rendus L39Académie Sci. - Ser. III - Sci. Vie 324, 743-755 (2001).

78. de Pontual, H. et al. New insights into behavioural ecology of European seabass off the West Coast of France: implications at local and population scales. ICES J. Mar. Sci 76, 501-515 (2019).

79. Climate Change 2007: The Physical Science Basis - IPCC (AR4).

80. Vinagre, C., Madeira, D., Narciso, L., Cabral, H. \& Diniz, M. Impact of climate change on coastal versus estuarine nursery areas: cellular and whole-animal indicators in juvenile seabass Dicentrarchus labrax. Mar. Ecol. Prog. Ser. 464, 237-243 (2012).

81. Anastasiadi, D., Díaz, N. \& Piferrer, F. Small ocean temperature increases elicit stage-dependent changes in DNA methylation and gene expression in a fish, the European sea bass. Sci. Rep 7, 12401 (2017).

82. Anderson, J. T. A Review of Size Dependent Survival During Pre-Recruit Stages of Fishes in Relation to Recruitment. 8, 12 (1988).

83. Strickland, J. D. H. \& Parsons, T. R. A practical handbook of seawater analysis. (Fisheries Research Board of Canada, 1972).

84. Lewis, E., Wallace, D., \& Allison, L. J. Program developed for CO \{sub 2$\}$ system calculations (No. ORNL/CDIAC-105). Brookhaven National Lab., Dept. of Applied Science, Upton, NY (United States); Oak Ridge National Lab., Carbon Dioxide Information Analysis Center, TN (United States). - Google Search. https://www.google.com/search?client=firefox-bdamp;channel=crowamp;q=69.\%09Lewis\%2C+E.\%2C +Wallace\%2C+D.\%2C+\%26+Allison\%2C+L.+J.+\%281998\%29. + Program + developed +for +CO +\%7Bs$\mathrm{ub}+2 \% 7 \mathrm{D}+$ system + calculations $+\% 28 \mathrm{No} .+105 \% 29 .+$ Brookhaven + National+Lab. $\% 2 \mathrm{C}+$ Dept. + of + Applied + Science $\% 2 \mathrm{C}+\mathrm{Up}$ ton $\% 2 \mathrm{C}+\mathrm{NY}+\% 28$ United + States $\% 29 \% 3 \mathrm{~B}+\mathrm{Oak}+$ Ridge + National + Lab. $\% 2 \mathrm{C}+$ Carbon+Dioxide +Information + Analysis + (1998).

85. Mehrbach, C., Culberson, C. H., Hawley, J. E. \& Pytkowicz, R. M. Measurement of the Apparent Dissociation Constants of Carbonic Acid in Seawater at Atmospheric Pressure1. Limnol. Oceanogr. 18, 897-907 (1973).

86. Dickson, A. G. \& Millero, F. J. A comparison of the equilibrium constants for the dissociation of carbonic acid in seawater media. Deep Sea Res. Part Oceanogr. Res. Pap 34, 1733-1743 (1987).

87. Gourtay, C. et al. Will global warming affect the functional need for essential fatty acids in juvenile sea bass (Dicentrarchus labrax)? A first overview of the consequences of lower availability of nutritional fatty acids on growth performance. Mar. Biol. 165 (2018).

88. Crane, R. K., Boge, G. \& Rigal, A. Isolation of brush border membranes in vesicular form from the intestinal spiral valve of the small dogfish (Scyliorhinus canicula). Biochim. Biophys. Acta 554, 264-267 (1979).

89. Holm, H., Hanssen, L. E., Krogdahl, A. \& Florholmen, J. High and low inhibitor soybean meals affect human duodenal proteinase activity differently: in vivo comparison with bovine serum albumin. J. Nutr 118, 515-520 (1988).

90. Métais, P. \& Bieth, J. [Determination of alpha-amylase by a microtechnic]. Ann. Biol. Clin. (Paris) 26, 133-142 (1968).

91. Bessey, O. A., Lowry, O. H. \& Brock, M. J. A Method for the Rapid Determination of Alkaline Phosphatase with Five Cubic Millimeters of Serum. J. Biol. Chem. 164, 321-329 (1946).

92. Maroux, S., Louvard, D. \& Barath, J. The aminopeptidase from hog intestinal brush border. Biochim. Biophys. Acta BBA - Enzymol 321, 282-295 (1973).

93. Bradford, M. M. A rapid and sensitive method for the quantitation of microgram quantities of protein utilizing the principle of protein-dye binding. Anal. Biochem. 72, 248-254 (1976).

94. Cominassi, L. Combined effects of ocean acidification and warming on a large pelagic fish, the European sea bass (Dicentrarchus labrax). PhD thesis, University of Hamburg. 2019. https://d-nb.info/1200548426/34. 


\title{
Acknowledgements
}

These data were originally published as part of the $\mathrm{PhD}$ thesis of $\mathrm{LC}^{94}$. The authors are grateful to all members of the Adaptation, Reproduction and Nutrition Lab from the Institut Français de Recherche et d'Exploitation de la Mer (IFREMER, Brest), past and present, who contributed to this work and to Aquastream company and to multiple reviewers for strengthening the focus of the manuscript. This work was funded by the FITNESS project (Deutsche Forschungemeinschaft, http://www.dfg.de/en/, PE 1157/8-1, MA 4271/3-1).

\section{Author contributions}

Cominassi, L., Moyano, M., Claireaux, G. \& Peck, M.A. contributed to the design and conception of the research, to the acquisition, analysis or/and interpretation of the data and to the writing of the manuscript. Howald, S., Mark, F.C., Zambonino-Infante, J.-L. helped carry out the experiment and draft the manuscript.

\section{Competing interests}

The authors declare no competing interests.

\section{Additional information}

Supplementary information is available for this paper at https://doi.org/10.1038/s41598-020-58846-2.

Correspondence and requests for materials should be addressed to L.C.

Reprints and permissions information is available at www.nature.com/reprints.

Publisher's note Springer Nature remains neutral with regard to jurisdictional claims in published maps and institutional affiliations.

\begin{abstract}
(c) (i) Open Access This article is licensed under a Creative Commons Attribution 4.0 International License, which permits use, sharing, adaptation, distribution and reproduction in any medium or format, as long as you give appropriate credit to the original author(s) and the source, provide a link to the Creative Commons license, and indicate if changes were made. The images or other third party material in this article are included in the article's Creative Commons license, unless indicated otherwise in a credit line to the material. If material is not included in the article's Creative Commons license and your intended use is not permitted by statutory regulation or exceeds the permitted use, you will need to obtain permission directly from the copyright holder. To view a copy of this license, visit http://creativecommons.org/licenses/by/4.0/.
\end{abstract}

(C) The Author(s) 2020 